\title{
Word-of-Mouth Communication as a Consequence of Relationship Quality in Online Environments
}

\section{José Ramón Sarmiento Guede ${ }^{1}$ Javier de Esteban Curiel ${ }^{2}$ Arta Antonovica $^{3}$}

Recibido: 2017-05-25

Enviado a pares: 2017-05-30
Aprobado por pares: 2017-10-10

Aceptado: 2017-10-24

DOI: 10.5294/pacla.2018.21.4.6

Para citar este artículo / to reference this article / para citar este artigo

Sarmiento, J. R., de Esteban, J. y Antonovica, A. (2018). Word-of-mouth communication as a consequence of relationship quality in online environments. Palabra Clave, 21(4), 1075-1106. doi: 10.5294/pacla.2018.21.4.6

\section{Abstract}

Electronic word-of-mouth (eWOM) communication generates content that constitutes an important source of information for users. Numerous researches have shown that the content of other users is more credible and influential than the content generated by the brand. The development of new technologies has brought about important changes in this process of interpersonal influence. However, studies analyzing the eWOM communication process are insufficient. In this sense, the main objective of this study is to examine the relationship quality with eWOM communication. In addition, trust, satisfaction and commitment are identified as the main dimensions that form the relationship quality, and we analyze how these dimensions are related and how they influence the development of eWOM

\footnotetext{
orcid.org/0000-0002-0342-0348. Universidad Rey Juan Carlos, España. joseramon.sarmiento@urjc.es

2 orcid.org/0000-0001-9735-286X. Universidad Rey Juan Carlos, España. javier.deesteban@urjc.es

3 orcid.org/0000-0002-9663-4168. Universidad Rey Juan Carlos, España. arta.antonovica@urjc.es
} 
communication. To achieve the objectives and the verification of the hypotheses, we developed a structural model with a multi-item scale of measurement adapted from previous studies. The questionnaire was filled out by 576 different people to empirically test the model. The study sample included users of online travel websites. Findings confirm that the quality of the relationship influences the development of eWOM communication. In addition, we were able to verify that the dimensions of satisfaction and trust in travel websites are the most determinant, mainly because users are looking for an interpersonal communication process that satisfies their need and that the source is reliable. The originality of this study is based on using the dimensions that best measure the quality of the relationship and analyzing how they influence the development of eWOM communication in an online context, very important aspects for the Spanish tourism sector.

\section{Keywords}

Electronic word-of-mouth communication; relationship quality; satisfaction; trust; commitment; relationship marketing (Source: Unesco Thesaurus). 


\section{La comunicación de voz a voz como consecuente de la calidad de la relación en entornos online}

\section{Resumen}

La comunicación de boca en boca electrónica genera contenido que constituye una importante fuente de información para los usuarios. Numerosas investigaciones han demostrado que es más creíble e influyente el contenido de otros usuarios que el contenido generado por la marca. El desarrollo de las nuevas tecnologías ha provocado cambios importantes en este proceso de influencia interpersonal. Sin embargo, los estudios que analizan el proceso de comunicación de boca en boca electrónica son insuficientes. En este sentido, este estudio tiene como objetivo principal examinar la relación entre la calidad de la relación y la comunicación de boca en boca electrónica. Además, se identifica la confianza, la satisfacción y el compromiso como principales dimensiones que forman la calidad de la relación y se analiza cómo dichas dimensiones están relacionadas e influyen en el desarrollo de la comunicación de boca en boca electrónica. Para la consecución de los objetivos y la constatación de las hipótesis, desarrollamos un modelo estructural con una escala de medición multi-ítem adaptada de estudios previos. Se recolectaron un total de 576 cuestionarios en línea válidos para probar empíricamente la medición del modelo. La muestra de estudio incluía usuarios de los sitios web de viajes online. Los hallazgos confirman que la calidad de la relación influye en el desarrollo de la comunicación de boca en boca electrónica. Además, pudimos comprobar que las dimensiones de la satisfacción y la confianza en los sitios web de viajes son las más determinantes, debido principalmente a que los usuarios buscan un proceso de comunicación interpersonal que satisfaga su necesidad y que dicha fuente sea fiable. La originalidad de este estudio se basa en utilizar las dimensiones que mejor miden la calidad de la relación y en analizar cómo influyen en el de- 
sarrollo de la comunicación de boca en boca electrónica en un contexto online, muy importante para el sector turístico español.

\section{Palabras clave}

Comunicación de boca en boca electrónica, calidad de la relación, satisfacción, confianza, compromiso, marketing de relaciones (Fuente: Tesauro de la Unesco). 


\section{Comunicação boca a boca como consequência da qualidade do relacionamento em ambientes online}

\section{Resumo}

A comunicação boca a boca eletrônica gera conteúdo que constitui uma importante fonte de informação para os usuários. Numerosas pesquisas mostraram que o conteúdo de outros usuários é mais credível e influente do que o conteúdo gerado pela marca. $\mathrm{O}$ desenvolvimento de novas tecnologias trouxe mudanças importantes neste processo de influência interpessoal. No entanto, os estudos que analisam o processo eletrônico de comunicação boca a boca são insuficientes. Nesse sentido, este estudo tem como objetivo principal examinar a relação entre a qualidade do relacionamento e a comunicação boca a boca eletrônica. Além disso, a confiança, a satisfação e o compromisso são identificados como as principais dimensões que formam a qualidade do relacionamento e se analisa a forma como essas dimensões estão relacionadas e como influenciam o desenvolvimento da comunicação boca a boca eletrônica. Para alcançar os objetivos e a verificação das hipóteses, desenvolvemos um modelo estrutural com uma escala de medida multi-item adaptada de estudos anteriores. Um total de 576 questionários online válidos foram coletados para testar empiricamente o modelo. A amostra do estudo incluiu usuários de sites de viagens on-line. Os resultados confirmam que a qualidade do relacionamento influencia o desenvolvimento da comunicação boca a boca eletrônica. Além disso, conseguimos verificar que as dimensões de satisfação e confiança nos sites de viagens são mais determinantes, principalmente porque os usuários estão procurando um processo de comunicação interpessoal que satisfaça suas necessidades e que a fonte seja confiável. A originalidade deste estudo baseia-se no uso das dimensões que melhor medem a qualidade do re- 
lacionamento e analisa a forma como influenciam o desenvolvimento da comunicação eletrônica boca-a-boca em um contexto online que é muito importante no setor turístico espanhol.

\section{Palavras-chave}

Comunicação boca a boca eletrônica, qualidade do relacionamento, satisfação, confiança, comprometimento, marketing de relacionamento (Fonte: Tesauro da Unesco). 


\section{Introduction}

Grönroos (1994) defined relationship marketing as "the process of identifying, establishing, maintaining, intensifying and, when necessary, finishing the relationship with the customers and other stakeholders" (p. 9). This could be achieved through a mutual exchange and through the fulfillment of promises. This definition was accepted by most international academics of the discipline, including Harker (1999), who, based on the seven categories of relationship marketing (i.e., birth/source, development/growth, maintenance, temporary, interaction, exits, and emotional content), concluded that Grönroos' definition seemed better because it included the fundamental conceptualization of relationship marketing. In order to determine the scope of our research, and after reviewing the topic and its multiple choices, we settle on Harker's appreciation and adopt it in this investigation.

It has been nearly 30 years since Leonard Berry (1983) used the concept of relationship marketing for the first time and, ever since, researchers have tried to identify the main areas of study covered by the term. In their paper research, Eiriz and Wilson (2006) tried to explain the axiomatic connections between the main areas, which, once focused not just individually but also collectively, allowed them to distinguish the three following sections on relationship marketing:

First, the study of rationality to create, develop, maintain and finish relationships. Here, it is crucial to clarify the concept of relation, as well as the typology of those relations depicted in relationship marketing, and to differentiate them from those that are not relations.

Second, the identification of the processes on which the relations are based, developed, maintained and, eventually, finished. At this point, it is of paramount importance to shape an explanation that includes the main related variables, such as trust, commitment, adaptation, uncertainty, dependency, and reciprocity. 
Third, the analysis of the suitable structures to manage those processes. It entails understanding how the companies are organized, how the networks are managed and which management structures are more or less useful.

The term relationship quality was introduced by Evert Gummesson (1987) to the researcher and professional marketing community in the context of a program about the quality of the Ericsson company in 1985, which drew the attention of numerous investigators due to having focused on the customer's perception of quality. Ever since then, the relationship quality has become one of the mainstays of relationship marketing (Hennig-thurau, Gwinner, Walsh, \& Gremler, 2004) and, nowadays, it is considered crucial for the development of successful commercial relations (Vieira, Winklhofer, \& Ennew, 2008). Relationship quality is defined as "a superordinate construct composed by different dimensions, though correlated" (Roberts, Varki, \& Brodie, 2003, p. 190) or as a multidimensional construct formed by trust, satisfaction, and commitment, and restricted by the customer's review. Relationship quality coincides with the second area of investigation of Eiriz and Wilson (2006) where the key relational dimensions, such as trust, commitment, and satisfaction, are essential for the process of identifying, establishing, developing and maintaining the relations with clients/customers. Taking this into account, we will approach our research focusing on this area and pose our model accordingly (Sarmiento-Guede, 2016).

The consequences of the relationship quality refer to how the concept at issue is connected with other concepts. In the existing literature, we have ascertained how the consequences vary depending on the context, which, according to Athanasopoulou (2009), can be classified into three main categories:

The first category comprises businesses, services, and channel efficiency in different ways, including the efficiency of the purchase, the utilization of market research, the supply chain performance, the throughput of the exports, the efficiency of the sales, the quality of the service, and the increased sales or the increased business. 
The second category includes relational benefits and the anticipation of future interaction; the length of the relation in time; the hoarding of clients; the social, economic, psychological and personalization benefits; the improvement on the relation and the continuity; aspects of voluntary relations, such as references, publicity or word-of-mouth (WOM) communication; the fidelity of the client; the future intentions with regard to the relation; the less-opportunist behavior; the propensity to leave the relation; the real value or perceived value for both parts. Customer loyalty has also gained the interest of researchers lately, either as a variable attitude, such as in purchase intentions or at a conceptual level of loyalty to the publication (Huang \& Chiu, 2006).

The last category includes all the variables related with satisfaction: the seller's satisfaction; economical and non-economical satisfaction; and the customer's satisfaction with the provider.

For our research, we chose WOM reviews, situated in the second category of consequences of Athanasopoulou's (2009) classification of relationship quality. Nowadays, eWOM communication is one of the most influential variables in the consumer's decision-making process. This phenomenon is due to the increasing number of consumers expressing their opinion, either positive or negative, about products, services or brands. This new way of WOM communication has received, during the last years, much attention from researchers. The investigations have focused on what leads to eWOM communication and how this way of communication affects the brand, the product, the service, the value or the customers fidelity (Zhang, Craciun, \& Shin, 2010).

\section{Objectives and Hypothesis of the Investigation}

Users used to have a passive role not that long ago. Actually, they used to simply surf the Internet and carry out electronic transactions, and therefore users did not contribute to online service development. However, the situation changed radically with the arrival of social media; thanks to its many formats (e.g., social networks, blogs, micro-blogging, online 
gaming, virtual worlds, forums, and contents communities), users can now create, upload, exchange content or communicate with other users. Therefore, users should be considered as actors and critics, insofar as a bad experience can affect the quality of the relation and, consequently, the WOM communication they will post online (Fassnacht \& Koese, 2006). Given this fact, we undertake the task of analyzing whether the quality of the relation has a positive effect on the online environments of WOM communication.

As a result, we formulate the following hypothesis in order to analyze the effects of online trust, online satisfaction and online commitment on eWOM communication:

H1 Online satisfaction has a positive effect on eWOM communication.

$\mathrm{H} 2$ Online trust has a positive effect on eWOM communication.

H3 Online commitment has a positive effect on eWOM communication.

\section{Methodology}

The methodology we used on this research is a quantitative analysis. The scenario we selected is the online touristic sector. The main reason for that choice was that we needed to apply homogeneity criteria to our sample due to the intense growth of the sector over the past year (Correa, García, \& Tabanera, 2015). We chose the Madrid Autonomous Community precisely because it is the region that generates more content on the online tourism sector and because young college/university students, the cluster with the highest affinity index (students aged 18 to 24 are the ones who use social media the most), all of which makes the scenario suitable for our research. To verify the abovementioned hypothesis, we used personal surveys in the form of questionnaires to gather information from a sample of 32,702 students from public and private universities from the Madrid Autonomous Community. The data gathering process took place from October 20 to 24 
of 2015. For more technical data on the survey technique, please see Figure 1 and Table 1 below.

\section{Figure 1. Socio-demographic features of the sample}

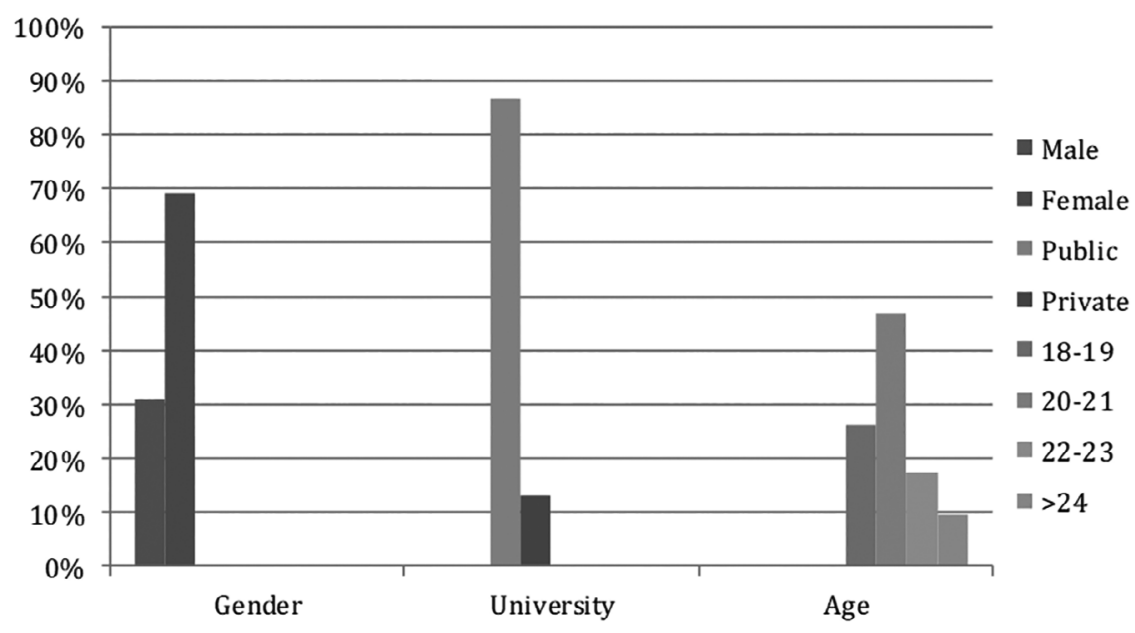

Source: Own elaboration.

\section{Table 1. Technical file of the research}

\begin{tabular}{|l|l|}
\hline \multicolumn{2}{|l|}{ Population and sample features } \\
\hline Geographical scope & Madrid Autonomous Community \\
\hline Population & University students \\
\hline Sample & Public and private university libraries \\
\hline Sample unit & Students between 18 and 24 years old \\
\hline Information gathering technique & Face-to-face survey \\
\hline Sampling error & $4.27 \%$ \\
\hline Trust level & $95 \%$ \\
\hline Average survey time & 10 minutes \\
\hline Sampling method & Simple stratified random sampling \\
\hline Sample size & 576 surveys \\
\hline Collecting period & October 20 to 24 of 2015, 10:00-14:00 and 16:00-19:00. \\
\hline Nonresponse rate & $0.03 \%$ \\
\hline Refusal rate & $4 \%$ \\
\hline Software used for the analysis & IBM/SPSS V.20 \\
\hline
\end{tabular}

Source: Own elaboration. 
The questionnaire consists of 17 questions related to the different touristic service websites (i.e., transportation, accommodation, opinion, destination, travel agencies, and web search engines). It included three differentiated paragraphs: The first one was a filter question to help us validate the research; the second paragraph was related to the dimension of the investigation (i.e., online satisfaction, online trust, online commitment, and eWOM communication); and the last paragraph consisted of questions that aimed to segment the groups that completed the survey.

The survey was answered by 576 people, with a sampling error of $4.27 \%$ and a $95 \%$ trust level. The convenience of the questionnaire was validated beforehand with a pre-test, based on a small group of people (30). For our questionnaire, we used multiple structured questions, using the Likert scale of 5 points, where 1 is "strongly disagree" and 5 is "strongly agree." While designing the questionnaire, we used items from previous researches in order to measure the dimensions. Finally, it is necessary to mention the treatment data method used, which was structural equations using the IBM SPSS software 20 (de Esteban, 2007; Antonovica, 2012).

\section{e-Relationship Quality}

The concept of $e$-Relationship quality emerges from the theory and research in the field of relationship marketing with the goal of strengthening the relations and creating customer loyalty (bonding). Relationship quality has been studied in depth. Authors such as Ulaga and Eggert (2006) and Athanasopoulou (2009) consider relationship quality as a superior-order construct consisting of several components or dimensions. Here, Hennig-Thurau and Klee (1997) define relationship quality as "the adequacy level of a relation to meet the needs of the customer involved" (p. 234). The relationship quality has to be interpreted as a multidimensional construct that "includes multiple angles of the relationship exchange, therefore, its structure and underlying dimensions vary between the empirical researches" (Palmatier, Dant, Grewal, \& Evans, 2006, p. 138). Despite the lack of agreement between researchers, the dimensions of trust, commitment and satisfaction prevail in most contexts and researches. Therefore, these three dimensions (trust, satisfaction, and commitment), posed to define relationship quality as a mul- 
tidimensional construct, could be considered as the most suitable for the current research (Sarmiento Guede, 2017).

\section{e-Satisfaction}

"Everybody knows what satisfaction is until you ask for a definition, and then it seems that nobody knows" (Zeithaml, Bitner, \& Gremler, 2013, p. 80 ). This quote we just mentioned comes from an expert researcher on satisfaction and illustrates accurately the challenge of defining that concept. Based on previous definitions, Oliver (1997) understood satisfaction as the response to consumer's realization. It is a judgment about a characteristic of the product or service, or the product or service itself, which pleases the customer in relation to the action of consuming.

When it comes to online services, the P2P interaction is replaced by Person-Computer interaction, and therefore this change could require different approaches for measuring satisfaction, as the online consumer is a buyer of products or services and, at the same time, a computer user. Online consumers cannot use their five senses for their decision-making process, but they face limited representations as pictures, videos, or text reviews.

In Szymanski and Hise's (2000) research, they understood electronic satisfaction as a global construct that shows the accumulated effect of an aggregate of individual experiences with the provider during a period of time. Therefore, you measure the intensity of the satisfaction or dissatisfaction with the online experience.

\section{e-Trust}

Online trust is understood as a "psychological status which involves the intention of accepting the vulnerability based on the positive expectations on the intentions or behaviors of others" (Rousseau, Sitkin, Burt, \& Camerer, 1998, p. 39). Aiming to understand online trust, we adopt the definition of offline trust in order to have a common base, seeing as it has been studied in multiple fields. In the researches about buyer-seller relations, offline trust works as a dimension that evolves throughout time, and it is based on the observation of the honesty, the reliability, the kindness and the trust of an agent (Ganesan, 1994). 
Once we have defined offline trust, we can focus on the digital context in order to understand online trust or the trust on the website, and then we will see the notorious difference, as the object of the online trust is the website, Internet or the technology. The website must be seen as an online company from the perspective of the customer's trust. We have to translate the business-client interaction to the user-website interactivity and consumers will develop their perceptions of the business according to that interactivity.

The better the impression the consumer has of the website, the more he accepts the vulnerability, and therefore he will gain trust towards that website. Therefore, online trust could be defined as the consumer's perception of how the website could meet his or her needs according to the information and the trust inspired by the website itself (Bart, Shankar, Sultan, \& Urban, 2005). Electronic trust is developed when consumers have positive impressions on the website when it comes to ecommerce, and so they accept the vulnerability. In practice, online trust could be defined as not having fear while being vulnerable (Sarmiento Guede, de Esteban Curiel, \& Antonovica, 2017).

\section{e-Commitment}

Offline commitment is defined as a psychological construct that represents the wish and determination to continue the participation in social media (Scanlan, Simons, Carpenter, Schmidt, \& Keeler, 1993) or as the strength of the psychological bond to an organization. The commitment has always been a key element in relationship marketing, specifically when talking about relationship quality. As proof, it has been demonstrated throughout marketing literature that both trust and satisfaction are precedents to the commitment.

Mukherjee and Nath (2007) understood online commitment as the natural association towards the website, which is similar to the affective bond at the offline context. In that research, they suggested that online trust affects online commitment directly and that it has a positive impact on behavioral intentions (WOM communication, purchase intent, and continuous interaction). Speaking of which, Eastlick, Lotz, and War- 
rington (2006) also suggested that online trust had a positive effect on online commitment and, consequently, on the online purchase intent in B2C (Business to Consumer). We believe that these researches provide proof of the relationship between online trust, online commitment, and behavioral intentions. Mukherjee and Nath (2007) conclude by stating that satisfaction with a website will affect both online trust and online commitment, as they are correlated.

\section{Electronic Word-of-Mouth Communication}

WOM communication has been the target of multiple researches for decades. Before cyberspace existed, authors such as Katz and Lazarsfeld (1955), Brooks (1957), Bearden and Etzel (1982), and Rogers (1983) looked into the concept as the oral communication between people, where the receptor perceives the message as non-commercial about a brand, product or service (Arndt, 1967). With the arrival of McLuhan's (1962) galaxy, eWOM was defined as the consumer's perception of the information provided by other users available online-i.e., the conversations available in discussion forums online (Belanche, Casaló, \& Guinalíu, 2012).

eWOM communication has experienced an enormous upswing during the past ten years, mainly because of the development of social media and also because of the great progress in e-commerce. These two reasons soon drew the attention of researchers and of marketing professionals, which led to results that are available for everyone. As a result, there are two trends in the researches made on eWOM communication:

- The one that studies the influence of eWOM communication on the behavior of consumers (Bickart \& Schindler, 2001).

- The one that studies the main reasons that lead consumers to exchange and look for information (Smith, Menon, \& Sivakumar, 2005).

It is obvious that eWOM communication is a recent phenomenon of investigation and has not been fully defined yet due to a lack of consensus between marketing and communication experts, among other reasons. 
Some authors like Hennig-Thurau, Gwinner, Walsh, and Gremier (2004) understand it as informal communication throughout the internet. However, the most complete definitions seem to be those provided by Litvin, Goldsmith, and Pan (2008), who define "electronic WOM as all informal communication on the Internet related to the use or particular characteristics of goods and services" (p. 460) and the one provided by Hennig-Thurau, Gwinner, Walsh, and Gremier (2004), who defined eWOM as "any statement, both positive and negative, made by potential customers, current or previous in a product or company, and that are available to a large audience (both individuals and companies) through the Internet" (p. 39). We observe that the definition refers to multiple transmitters and receivers, which poses a problem.

By transmitters and receivers, on the other hand, Hennig-Thurau, Gwinner, Walsh, and Gremier (2004) mean any potential, current or previous customer. However, Xun and Reynolds (2010) criticized Hennig-Thurau's definition, arguing that the transmitter or receiver is not a customer at all. They adduced that the conceptualization was too static and did not match with the interactive exchange of information that eWOM offers. In fact, the latest researches focus more on its influence on the user/customer than on the plain exchange of opinions and search of information.

eWOM is a complex concept that used to be related to numerous terms, such as viral marketing, internet communication, user-generated content (UGC), internet advertising, among others. It is very different from those concepts, though, seeing as eWOM is an interactive process that includes numerous elements. Indeed, Breazeale (2008) asserted that eWOM could not be the same as WOM. Given these evident differences, as we will point out below, and taking into account the researches of Lee and Youn (2009) and Breazeale (2009), we identified a series of aspects that could help to differentiate these two concepts (electronic and non-electronic WOM):

eWOM is not an oral activity. Indeed, according to Pollach (2008), the digital context has many platforms (i.e., social media) that help eWOM. 
Furthermore, as we mentioned before, WOM takes place in a physical situation, face to face, where agents share information about a product, service, brand or organization. eWOM, on the other hand, takes place through different devices that keep and share the information (e.g., computers, tablets, smartphones, etc.). In WOM, the face-to-face context disappears and, as a result, the physical and verbal features that allow one person to evaluate the other are nonexistent (Gelb \& Sundaram, 2002). Moreover, even though the oral word can have a great impact because of its immediacy, the written word has the advantage of permanence in time (Bickart \& Schindler, 2001).

eWOM facilitates the exchange of opinions between customers. Internet and, in particular, social media, offers consumers the opportunity to exchange information. eWOM makes it possible to compile information about organizations/companies, brands, products or services from other consumers or customers in an unbiased way, as well as to offer your own advice about the consumption. In this sense, electronic word of mouth works as a process of social influence in which users experience changes in their attitudes and behaviors as a result of interacting with other users. It has been proven that users look for the opinion of third parties aiming to reduce their own risk, ensure lower prices and obtain reliable information (Goldsmith \& Horowitz, 2006).

eWOM has opinion leaders. Just as in the analogical context, the digital context has its own opinion leaders. Bronner and de Hoog (2010) define opinion leaders in digital context as e-fluentials. In general terms, these are the most experienced users that have an influence on other users' decisions with their information supply (Fong \& Burton, 2006). On this subject, Vilpponen, Winter, and Sundqvist (2006) state that opinion leaders have an important role when it comes to spreading innovation online.

eWOM occurs in and throughout Internet platforms. Social media has enabled users to gain market power from the producers. Now it is possible 
to be a provider, a transmitter or an information seeker (Sun, Youn, $\mathrm{Wu}$, $\&$ Kuntaraporn, 2006). The Internet emerges as the channel that drastically changed WOM. It has even eased indirect communications between anonymous people through different platforms that exist in the Internet (i.e., social media, including blogs, social networks, community content, forums, etcetera).

eWOM is sustained by the web. Vilpponen, Winter, and Sundqvist (2006) state that eWOM is based on messages that are linked altogether, thus forming a web of webs. As Dellarocas (2003) stated, users in virtual communities build up their own social networks with people they do not know and exchange with them opinions on products and brands. This process takes place in any virtual community where users do not establish a relationship most of the times, but they merely connect because of a common interest. Users make decisions offline based on opinions and information they find online (Lee, Park, \& Han, 2008).

eWOM is addressed to a large audience. One of the main benefits that induce customers to use it is its long-range capability. The Internet has made it possible for eWOM to be "from many to many," not only from one to many, and the content is available for numerous users (Hennig-Thurau, Gwinner, Walsh, \& Gremier, 2004), which makes it more interactive than non-electronic WOM (Gelb \& Sundaram, 2002). Social media provides dynamic, interactive, multimedia and social platforms for the development of eWOM.

eWOM is a timeless and placeless interaction. Hence, it is an asynchronous process not limited by time or place (Goldsmith \& Horowitz, 2006). As eWOM does not disappear instantly (Breazeale, 2009), marketing investigators and academicians can undertake the task of studying its groups and communities through netnography (Xun \& Reynolds, 2010). In conclusion, users are able to read, reread and compare opinions filed about the products, services, brands or companies they are interested in. This 
accessibility makes WOM that attractive for the Internet user, becoming his or her preferred source of information (Hoffman \& Novak, 1997).

eWOM can be anonymous. Another important difference between electronic and non-electronic WOM is that eWOM can be anonymous. In several occasions, eWOM electronic word of mouth takes place between unrelated people (Dellarocas, 2003), but thanks to the anonymity provided by online communication, users tend to lose their fear and share way more information, increasing the volume of eWOM. As a result, the chances of finding other users with experience on the service, product, brand or company at issue are remarkably increased. However, one of the negative aspects of anonymity is that, remaining the source unknown the message credibility decreases (Amblee \& Bui, 2011). Users tend to fall back on friends, family and influencers with great online reputation. As a result, with the rise of blogs and social networks, anonymity is giving ground, as users interact in a more personal way.

In eWOM, credibility issues can be detected. There is a great discussion in the internet about if all that non-filtered information provided by unknown users should be treated as truthful. Indeed, if the information generated through eWOM is to be treated as truthful, it must be checked and validated by some receivers (users). Several researches state that information generated by the users has more credit than the organization itself.

A number of investigations conclude that WOM communication affects all online business directly (Cheung, Lee, \& Rabjohn, 2008). The relationship between commitment and WOM communication (Harrison-Walker, 2001; Lee, Park, \& Han, 2008; Casaló, Flavián, \& Guinalíu, 2008), the relationship between trust and WOM communication (Chung \& Shin, 2010), the relationship between satisfaction and WOM communication (Casaló, Flavián, \& Guinalíu, 2008; Casaló, Flavián, \& Guinalíu, 2012) are also demonstrated, both in analogical and digital contexts. In this paragraph, we will explain WOM communication as a consequence of the quality of the relation (Athanasopoulou, 2009). 


\section{Analysis and Result Interpretation}

In this paragraph, we will introduce the analysis and results obtained from the 576 interviews with users of tourist service websites (i.e., transportation, hosting, opinion, meta-browsers, destination and travel agencies websites). The percentages shown in the following charts are calculated according to the size of the sample (576 surveys) through simple random sampling. This method allowed us to obtain a representative sample, both in shape and size, for our research.

Before contrasting the hypothesis, we analyzed the reliability of the constructs using the Cronbach's alpha coefficient for all the scales, obtaining values over 0.790 for trust $(0.890)$, satisfaction ( 0.935$)$, commitment (0.897), and eeWOM communication (0.938). As you see, all the values under study are over 0.60 , so we can conclude that there is a high constancy and reliability between the statements included in the questionnaire (Hair et al., 2010).

Table 2 shows the Pearson correlation coefficient as well as the average of the dimensions, which rate how correlated the variables are on a $0-1$ scale. According to Hernández-Sampieri, Fernández-Collado, and Baptista-Lucio (2010), Pearson correlations are significant from 0.30 . The results show there is a relation between the variables of satisfaction, trust, commitment and eWOM communication.

\section{Table 2. Hypothesis contrast out of Pearson correlation coefficient}

\begin{tabular}{|l|c|c|c|c|c|c|}
\hline & Mean & Typical deviation & $\mathbf{1}$ & $\mathbf{2}$ & $\mathbf{3}$ & $\mathbf{4}$ \\
\hline 1 eWOM communication & 4.75 & 1.460 & 1.000 & & & \\
\hline 2 Satisfaction & 4.58 & 1.409 & 0.423 & 1.000 & & \\
\hline 3 Trust & 4.09 & 1.456 & 0.543 & 0.634 & 1.000 & \\
\hline 4 Commitment & 3.38 & 1.578 & 0.565 & 0.592 & 0.624 & 1.000 \\
\hline
\end{tabular}

Note: 1 is eWOM communication; 2 is satisfaction; 3 is trust; and 4 is commitment.

Source: Own elaboration. 
In order to contrast the hypothesis, we used the linear regression analysis. With this statistical technique, we aim to analyze the relation between a dependent variable - in this case, eWOM communication-and several independent variables such as trust, satisfaction, and commitment. Table 3 shows there is a positive relation between satisfaction and eWOM communication $(t=6.057, p=.000)$. As a consequence of this, we accepted hypothesis $\mathrm{H}_{1}$. The study also showed a positive correlation between trust and eWOM communication $(\mathrm{t}=6.285 ; \mathrm{p}=.000)$, and therefore we accepted hypothesis $\mathrm{H}_{2}$. Finally, the results also showed that WOM communication also affects commitment $(\mathrm{t}=2.419 ; \mathrm{p}=.001)$, and so we accepted hypothesis $\mathrm{H}_{3}$ as well.

\section{Table 3. Regression analysis of the impact of quality of the service on the satisfaction of online users}

\begin{tabular}{|l|c|c|c|c|c|}
\hline \multirow{2}{*}{ Model } & \multicolumn{2}{|c|}{ Nonstandard coefficients } & $\begin{array}{c}\text { Standard } \\
\text { coefficient }\end{array}$ & t & Sig. \\
\cline { 2 - 6 } & B & Std. Dev. & Beta & B & Std. Dev. \\
\hline (Constant) & 1.198 & .298 & & 6.144 & .000 \\
\hline Satisfaction & .175 & .034 & .202 & 6.057 & $.000^{*}$ \\
\hline Trust & .214 & .041 & .235 & 6.285 & .000 \\
\hline Commitment & .145 & .062 & .141 & 2.419 & $.012^{* *}$ \\
\hline
\end{tabular}

Note: $R^{2}=0.774 ;$ F-value $=42.484, p>0.000$.

${ }^{*}$ Significant at $1 \%$, ** Significant at $5 \%$

Source: Own elaboration.

The $\mathrm{R}^{2}$ coefficient of 0.774 shows that the model is relevant, as $77 \%$ of the satisfaction, trust and commitment of the users is related with eWOM communication. The p-value for the model is under 0.05 , which means that the stated hypothesis could be accepted as well as at least one of the parameters being nonzero, and thus the model is valid as a whole. All of these results corroborate the existing relation between WOM communication and the relationship quality as stated by Athanasopoulou (2009), Chung and Shin (2010), and Sarmiento-Guede (2015). 


\section{Conclusions, Limitations and Future Lines of Investigation}

The Oxford Dictionary (2009) defines conclusion as "the end or finish of an event, process, or text," as well as "the summing-up of an argument or text or a proposition that is reached from given premises." This paragraph encompasses the main conclusions extracted from the investigation we carried out after reviewing a vast theoretical framework, aside from the scientific application throughout different techniques, both on data gathering and primary data analysis.

Our theoretical contribution rests on embodying some more precise definitions to the concepts of study. In this respect, we understand satisfaction as the affective state of the client/customer related to the performance of the product, service, brand, or relation meeting or exceeding expectations. We understand trust as the hope, security, reliability and integrity that clients/customers have in the products, services or brands. We understand commitment as the obligation of continuing an established relation. And lastly, we define eWOM communication as the exchange of information, either positive or negative, between actual and/or potential customers about a product, service or brand.

To answer the main question of the research: proving whether the quality of the relation had a positive effect on eWOM communication, we appealed to the results of the hypothesis validation. Hence, the hypotheses have proved that there is a positive relation between all the variables (online satisfaction, trust, and commitment) with eWOM communication.

From the proposed model, it is concluded that satisfaction and trust through travel websites are the most important direct predictors of eWOM communication, mainly because users are looking for an interpersonal communication process that satisfies their need and a source that is reliable. However, commitment through travel websites does not show such a significant relationship, mainly because users do not use these types of websites to develop a relationship with the brand. 
Research work like the one by Naik, Shankar, Venkatesh, and Hofacker (2010) concluded that dimensions such as customer satisfaction are antecedents and mediators of behavioral intentions, and since 1980 it has been established that the highest levels of satisfaction have a greater intention to recommend, that is, to develop eWOM communication. The results showed that the variables of trust, satisfaction and commitment explain on a $77 \%$ the model proposed and how it affects WOM communication.

Based on the analysis presented, we can conclude that users use more websites from travel agencies, opinion websites like TripAdvisor, and search engines. The main reason for using travel agency websites is because of how easy they make it for users have to book, compare prices and see content on the same website. Regarding opinion websites such as TripAdvisor, the main reason to use them is that users can develop WOM communication with other users, which enriches these types of websites as a source of reliable information. With respect to the last price comparison website, we can say that users are only one click away from all the necessary information regarding prices. In the end, it can be said that a quality travel website must gather the variables of content, price comparison and tools that facilitate the development of WOM communication, which is the most important after the study.

Several research studies similar to the present work suggest the relationship between the quality of the relationship and the development of electronic mouth-to-mouth communication. Authors such as Chung and Shin (2010) propose a model in which they confirm the relationship and influence of the online relationship quality in eWOM communication. This model used a sample of young university students from South Korea in the context of e-commerce. Other authors such as Lee and Youn (2009) demonstrated that satisfied online shopping customers develop positive e-mail communication, while unsatisfied customers develop negative e-mail communication. More recent studies, such as the one by Purnasari and Yuliando (2015), show the relationship between the quality of the relationship and the development of eWOM communication in the Indonesian beverage and food sector. 
Our research also had a task of demonstrating the need to focus academic marketing studies on the business sector. Consequently, our recommendation for travel website companies is to use their websites as well as their social media accounts to manage their relationship with their clients. A good quality of the relationship will grant them a positive eWOM communication, as we have shown in this research.

Next, we will list the limitations we set to our research: a) the sample was limited to university students between the ages of 18 and 24 years from the Autonomous Community of Madrid, Spain. Even though we see it as a representative sample, we do not think it is big enough to extrapolate the results to all students in Spain; b) the sample focused on a specific sector that can limit the scope if we ever extrapolate the results to different sectors; and c) we found a lack of investigation on eWOM communication, which limited the bibliography references and hindered the measurement.

Until now, we referred to the theoretical and empirical contributions and the implications this research could have on business management as well as the limitations we found during the investigation process. However, we believe it is as important or even more, to open new lines of investigation that offer other researchers the opportunity to develop new investigations in the area. That is why we have paid so much attention to this paragraph.

Hence, in next researches, both eWOM communication and the content generated by the users could be studied more in depth. It is crucial that we define each concept correctly and that we differentiate them in order to avoid confusions.

Focusing on WOM communication and user-generated content, it is very interesting to understand how those dimensions affect the users' behavior - that is, to know if there is any positive or negative relationship regarding the purchase of products/services.

This research work to protect research subjects and institutions has at all times preserved the confidentiality of all primary and secondary sources, thus complying with ethical research principles. 


\section{References}

Amblee, N., \& Bui, T. (2011). Harnessing the influence of social proof in online shopping: The effect of electronic word of mouth on sales of digital microproducts. International Journal of Electronic Commerce, 16(2), 91-114. 114. doi: 10.2753/JEC1086-4415160205.

Antonovica, A. (2012). Comunicación e imagen de los países bálticos en España a través de la técnica del discurso periodístico (Vol. 156). Madrid, Spain: Dykinson.

Arndt, J. (1967). Word-of-mouth advertising and informal communication. In D. Cox (Ed.), Risk taking and information handling in consumer behaviour (pp. 172-187). Boston, MA: Harvard Business School.

Athanasopoulou, P. (2009). Relationship quality: A critical literature review and research agenda. European Journal of Marketing, 43(5/6), 583-610. doi: 10.1108/03090560910946945

Bart, Y., Shankar, V., Sultan, F., \& Urban, G. L. (2005). Are the drivers and role of online trust the same for all web sites and consumers? A largescale exploratory empirical study. Journal of Marketing, 69(4), 133152. doi: $10.1509 / j m k g .2005 .69 .4 .133$

Bearden, W. O., \& Etzel, M.J. (1982). Reference group influence on product and brand purchase decisions. Journal of Consumer Research, 9(2), 183-194. Retrieved from https://www.jstor.org/stable/2489127.

Belanche, D., Casaló, L. V., \& Guinalíu, M. (2012). Website usability, consumer satisfaction and the intention to use a website: The moderating effect of perceived risk. Journal of Retailing and Consumer Services, 19(1), 124-132. 132. doi: 10.1016/j.jretconser.2011.11.001.

Berry, L. L. (1983). Relationship marketing. In L. L. Berry, G. Lynn Shostack, \& G. Upah (Eds.), Emerging perspectives on services marketing (pp. 25-28). Chicago, IL: American Marketing Association. 
Bickart, B., \& Schindler, R. M. (2001). Internet forums as influential sources of consumer information. Journal of interactive marketing, 15(3), 31-40. doi: 10.1002/dir.1014.

Breazeale, M. (2009). Forum - Word of Mouse - An assessment of electronic word-of-mouth research. International Journal of Market Research, 51(3), 297-318. doi: 10.2501/S1470785309200566.

Bronner, F., \& Hoog, R. D. (2010). Consumer-generated versus marketer-generated websites in consumer decision making. International Journal of Market Research, 52(2), 231-248. doi: 10.2501/ S1470785309201193.

Brooks, J. L. (1957). The systematics of North American Daphnia. New Haven, CT: The Academy.

Casaló, L. V., Flavián, C., \& Guinalíu, M. (2008). The role of satisfaction and website usability in developing customer loyalty and positive wordof-mouth in the e-banking services. International Journal of Bank Marketing, 26(6), 399-417. doi: 10.1108/02652320810902433.

Casaló, L. V., Flavián, C., \& Guinalíu, M. (2012). Redes sociales virtuales desarrolladas por organizaciones empresariales: antecedentes de la intención de participación del consumidor. Cuadernos de Economía y Dirección de la Empresa, 15(1), 42-51. doi: 10.1016/j. cede.2011.06.003

Cheung, C. M., Lee, M. K., \& Rabjohn, N. (2008). The impact of electronic word-of-mouth: The adoption of online opinions in online customer communities. Internet Research, 18(3), 229-247. doi: $10.1108 / 10662240810883290$

Chung, K.H., \& Shin, J. I. (2010). The antecedents and consequences of relationship quality in internet shopping. Asia Pacific Journal of Marketing and Logistics, 22(4), 473-491. doi:10.1108/13555851011090510 
Correa, M., García, J. R., \& Tabanera, A. (2015). Comercio electrónico y hábitos de consumo en España: la importancia de la banca on-line. Retrieved from https://www.bbvaresearch.com/publicaciones/ comercio-electronico-y-habitos-de-consumo-enespana-la-importancia-de-la-banca-on-line/

de Esteban Curiel,J. (2007). La demanda del turismo cultural y su vinculación con el medio ambiente urbano los casos de Madrid y Valencia (Doctoral dissertation). Universidad Complutense de Madrid, Spain.

Dellarocas, C. (2003). The digitization of word of mouth: Promise and challenges of online feedback mechanisms. Management Science, 49(10), 1407-1424. Retreived from http://ccs.mit.edu/dell/digitization\%20of\%20word-of-mouth.pdf

Eastlick, M. A., Lotz, S. L., \& Warrington, P. (2006). Understanding online B-to-C relationships: An integrated model of privacy concerns, trust, and commitment. Journal of Business Research, 59(8), 877886. doi: 10.1016/j.jbusres.2006.02.006

Eiriz, V., \& Wilson, D. (2006). Research in relationship marketing: Antecedents, traditions and integration. European Journal of Marketing, 40(3/4), 275-291. doi: 10.1108/03090560610648057

Fassnacht, M., \& Koese, I. (2006). Quality of electronic services conceptualizing and testing a hierarchical model. Journal of Service Research, 9(1), 19-37. doi: 10.1177/1094670506289531

Fong, J., \& Burton, S. (2006). Electronic word-of-mouth: A comparison of stated and revealed behavior on electronic discussion boards. Journal of Interactive Advertising, 6(2), 7-62. doi: $10.1080 / 15252019.2006 .10722119$

Ganesan, S. (1994). Determinants of long-term orientation in buyer-seller relationships. Journal of Marketing, 1-19. Retreived from https:// www.jstor.org/stable/pdf/1252265.pdf 
Gelb, B. D., \& Sundaram, S. (2002). Adapting to "word of mouse”. Business Horizons, 45(4), 21-25.

Goldsmith, R. E., \& Horowitz, D. (2006). Measuring motivations for online opinion seeking. Journal of Interactive Advertising, 6(2), 2-14.

Gronroos, C. (1994). Marketing y gestión de servicios: la gestión de los momentos de la verdad y la competencia en los servicios. Ediciones Díaz de Santos.

Gummesson, E. (1987). The new marketing-developing long-term interactive relationships. Long Range Planning, 20(4), 10-20.

Hair, J. F., Bush, R. P., \& Ortinau, D. J. (2010). Investigación de mercados en un ambiente de información digital. México, DF: McGraw Hill Interamericana de España.

Harker, M. J. (1999). Relationship marketing defined? An examination of current relationship marketing definitions. Marketing Intelligence \& Planning, 17(1), 13-20. doi: 10.1108/02634509910253768.

Harrison-Walker, L. J. (2001). The measurement of word-of-mouth communication and an investigation of service quality and customer commitment as potential antecedents. Journal of Service Research, 4(1), 60-75. doi: 10.1177/109467050141006.

Hennig-Thurau, T., \& Klee, A. (1997). The impact of customer satisfaction and relationship quality on customer retention: A critical reassessment and model development. Psychology \& Marketing, 14(8), 737-764. doi: 10.1002/(SICI)15206793(199712)14:8<737::AID-MAR2>3.0.CO;2-F

Hennig-Thurau, T., Gwinner, K. P., Walsh, G., \& Gremler, D. D. (2004). Electronic word-of-mouth via consumer-opinion platforms: What motivates consumers to articulate themselves on the Internet? Journal of Interactive Marketing, 18(1), 38-52. doi: 10.1002/dir.10073. 
Hernández Sampieri, R., Fernández Collado, C., \& Baptista Lucio, P. (2010). Metodología de la investigación. México, DF: Editorial McGraw Hill.

Hoffman D. L., \& Novak, H. T. P. (1997). A new marketing paradigm for electronic commerce. The Information Society, 13(1), 43-54. doi: $10.1080 / 019722497129278$

Huang, H.-H., \& Chiu, C.-K. (2006). Exploring customer satisfaction, trust and destination loyalty in tourism. Journal of American Academy of Business, 10, 156-159.

Katz, E., \& Lazarsfeld, P. F. (1955). Personal influence: The part played by people in the flow of mass communications. New York, NY: The Free Press.

Lee, J., Park, D. H., \& Han, I. (2008). The effect of negative online consumer reviews on product attitude: An information processing view. Electronic Commerce Research and Applications, 7(3), 341-352. doi: 10.1016/j.elerap.2007.05.004.

Lee, M., \& Youn, S. (2009). Electronic word of mouth (eWOM): How eWOM platforms influence consumer product judgement. International Journal of Advertising, 28(3), 473-499. doi: 10.2501/ S0265048709200709.

Litvin, S. W., Goldsmith, R. E., \& Pan, B. (2008). Electronic word-of-mouth in hospitality and tourism management. Tourism Management, 29(3), 458-468. doi: 10.1016/j.tourman.2007.05.011.

Mukherjee, A., \& Nath, P. (2007). Role of electronic trust in online retailing: A reexamination of the commitment-trust theory. European Journal of Marketing, 41(9/10), 1173-1202. doi: 10.1108/03090560710773390.

Oliver, R. L. (1997). Satisfaction: On a behavioral perspective on the consumer. New York, NY: McGraw-Hill. 
Oxford, O. E. (2009). Oxford English Dictionary. Oxford, UK: Oxford University Press.

Palmatier, R., Dant, R., Grewal, D., \& Evans, K. (2006). Factors influencing the effectiveness of relationship marketing: A meta-analysis. Journal of Marketing, 70(4), 136-153. doi: 10.1509/jmkg.70.4.136.

Pollach, I. (2008). Electronic word-of-mouth: Agenre approach to consumer communities. International Journal of Web Based Communities, 4(3), 284-301. doi: 10.1504/IJWBC.2008.01919.

Purnasari, H., \& Yuliando, H. (2015). How relationship quality on customer commitment influences positive e-WOM. Agriculture and Agricultural Science Procedia, 3, 149-153. doi: 10.1016/j.aaspro.2015.01.029.

Roberts, R. Varki, S., \& Brodie, R. (2003). Measuring the quality of relationships in consumer services: An empirical study. European Journal of Marketing,37(1/2), 169-196. doi: 10.1108/03090560310454037.

Rogers, R. W., (1983). Cognitive and physiological processes in fear appeals and attitude change: A revised theory of protection motivation. Social Psychophysiology, 153-176.

Rousseau, D. M., Sitkin, S. B., Burt, R. S., \& Camerer, C. (1998). Not so different after all: A cross-discipline view of trust. Academy of Management Review, 23(3), 393-404. Retreived from http://citeseerx.ist. psu.edu/viewdoc/download?doi=10.1.1.470.8322\&rep=rep1\&type $=\mathrm{pdf}$

Sarmiento-Guede, J. R. (2015). Marketing de relaciones: aproximación a las relaciones virtuales. Madrid: Dykinson.

Sarmiento-Guede, J. R. (2016). Las relaciones en el marketing: una revisión a su evolución. Anuario Jurídico y Económico Escurialense, 49, 459-474. 
Sarmiento-Guede, J. R. (2017). Marketing de relaciones: un análisis del contenido de sus fundamentos teóricos. Anuario Jurídico y Económico Escurialense, 50, 279-400.

Sarmiento-Guede, J. R., de Esteban Curiel, J., \& Antonovica, A. (2017). La comunicación viral a través de los medios sociales: análisis de sus antecedentes. Revista Latina de Comunicación Social, 72, 6986. doi: 10.4185/RLCS-2017-1154.

Scanlan, T. K., Simons, J. P., Carpenter, P. J., Schmidt, G. W., \& Keeler, B. (1993). The sport commitment model: Measurement development for the youth-sport domain. Journal of Sport \& Exercise Psychology, 15(1), 16-38.

Shankar, V., Venkatesh, A., Hofacker, C., \& Naik, P. (2010). Mobile marketing in the retailing environment: Current insights and future research avenues. Journal of Interactive Marketing, 24(2), 111-120. doi: 10.1016/j.intmar.2010.02.006.

Smith, D., Menon, S., \& Sivakumar, K. (2005). Online peer and editorial recommendations, trust, and choice in virtual markets. Journal of Interactive Marketing, 19(3), 15-37. doi: 10.1002/dir.20041.

Sun, T., Youn, S., Wu, G., \& Kuntaraporn, M. (2006). Online word-of-mouth (or mouse): An exploration of its antecedents and consequences. Journal of Computer-Mediated Communication, 11(4), 1104-1127. doi: 10.1111/j.1083-6101.2006.00310.x.

Szymanski, D. M., \& Hise, R. T. (2000). E-satisfaction: An initial examination. Journal of Retailing, 76, 309-322. doi: 10.1016/S00224359(00)00035-X.

Ulaga, W., \& Eggert, A. (2006). Relationship value and relationship quality: Broadening the nomological network of business-to-business relationships. European Journal of Marketing, 40(3/4), 311-327. doi: 10.1108/03090560610648075. 
Vieira, A. L., Winklhofer, H., \& Ennew, C. T. (2008). Relationship quality: A literature review and research agenda. Journal of Customer Behavior, 7(4), 269-291. doi: 10.1362/147539208X386833.

Vilpponen, A., Winter, S., \& Sundqvist, S. (2006).Electronic word-of-mouth in online environments: exploring referral network structure and adoption behavior. Journal of Interactive Advertising, 6(2), 71-86. doi: 10.1080/15252019.2006.10722120.

Xun, J., \& Reynolds, J.J. (2010). Applying netnography to market research: The case of the online forum. Journal of Targeting, Measurement and Analysis for Marketing, 18(1), 17-31. doi: 10.1057/jt.2009.29.

Zeithaml, V. A., Bitner, M. J., \& Gremler, D. D. (2013): Marketing de servicios. Mexico: McGraw-Hill.

Zhang, J. Q. Craciun, G., \& Shin, D. W. (2010). When does electronic word-of-mouth matter? A study of consumer product reviews. Journal of Business Research, 63(12), 1336-1341. doi: 10.1016/j. jbusres.2009.12.011. 